INJECT (Interdisciplinary Journal of Communication) p-ISSN: 2548-5857; e-ISSN: 2548-7124

Vol. 4. No. 2 Desember 2019: p. 153-174

website: http://inject.iainsalatiga.ac.id/index.php/INJECT/index

\title{
EFFECTS OF EXPOSURE TO MASS MEDIA MESSAGES ON TEENAGE VEILED PERCEPTIONS
}

\author{
Ridwan Rustandi \\ Universitas Islam Negeri Sunan Gunung Djati Bandung, Indonesia \\ ridwanrustandi@uinsgd.ac.id \\ Khoiruddin Muchtar \\ Universitas Islam Negeri Sunan Gunung Djati Bandung, Indonesia
}

\begin{abstract}
The purpose of this study was to determine the impact on the soap opera Aisyah Putri that aired on the private television station RCTI. This study uses a qualitative approach by relying on George Gebner's theory of states that television shows affect the audience. Data collection techniques through observation and interviews are three main aspects, namely cognitive, affective and conative, related to the effects of exposure to mass media messages. Female students of Al-Biruni High School in Bandung consisting of classes X, XI, and XII. The results of the study showed that the process of perception of teenagers on Aisyah Putri soap opera shows the stages of sensation, perception, and confirmation (memory and thinking). The motive for the use of headscarves for teenagers. The headscarf perception among adolescents, especially for students at Albiruni Cerdas Mulia Bandung High School has a strong influence on exposure to "Aisyah Putri" religious soap operas in terms of cognitive, affective and conative.
\end{abstract}

Keywords: Effects of Insured Media; Mass Media Messages; Veiled Perception.

\begin{abstract}
Abstrak
Tujuan penelitian ini adalah untuk mengetahui dampak pada sinetron Aisyah Putri yang ditayangkan oleh stasiun televisi swasta RCTI. Penelitian ini menggunakan pendekatan kualitatif dengan mengandalkan teori George Gebner menyatakan bahwa acara televisi mempengaruhi penonton. Teknik pengumpulan data melalui observasi dan wawancara adalah tiga aspek utama, yaitu kognitif, afektif dan konatif, terkait dengan efek paparan pesan media massa. Siswa perempuan SMA Al-Biruni di Bandung terdiri dari kelas X, XI, dan XII. Hasil penelitian menunjukkan bahwa proses persepsi remaja pada sinetron Aisyah Putri menunjukkan tahapan sensasi, persepsi, dan konfirmasi (ingatan dan pemikiran). Motif penggunaan jilbab untuk remaja. Persepsi jilbab di kalangan remaja, terutama bagi siswa di SMA Albiruni Cerdas Mulia Bandung memiliki pengaruh yang kuat dari paparan sinetron agama "Aisyah Putri" dalam hal kognitif, afektif dan konatif.
\end{abstract}

Kata kunci: Effects of Insured Media; Mass Media Messages; Veiled Perception. 


\section{Introduction}

The era of globalization has a new influence on the development of the culture of society. Geographical boundaries which initially became one of the demarcation lines (boundaries) between one nation and another are now beginning to disappear as well as influencing the sustainability of human life in various aspects. In terms of culture, for example, the entry and spread of a nation's culture has a significant influence on the development of the current globalization. This has led to the deterioration of culture, where the sophistication of information technology provides an opportunity to mix various cultures in the world.

Foreign culture in Indonesia is considered easy to enter and spread in the community. Generally, the external culture was introduced through mass media, in demand even to the point of being imitated mainly by teenagers. Lately, for example, eastern culture has dominated the lives of Indonesian teenagers, ranging from hairstyles to fashion.

In recent years, the eastern cultures of Korea and Japan have developed quite rapidly in our country. Indonesian society, especially among teenagers, mimics Korean and Japanese cultures. Starting from the genre of music, fashion (fashion), hairstyles, accessories, and language. The development of the phenomenon of boyband which is widely imitated by teenagers is quite a proof of the ease with which foreign cultures enter Indonesia. Indonesian teenagers easily imitate new things that are seen as a trend of existing cultural developments.

The style of fashion in the use of headscarves as a cover for genitals for women who are Muslim (Muslim) is also influenced by the development of external culture. Muslim dress styles from time to time are always up to date (following the latest fads). The conception of the use of headscarves in shariáh (based on Islamic teachings) is used as a cover of genitals with certain restrictions, nowadays it is beginning to be conceived of as a style or fashion dress that is popularly packaged. So, sometimes 
the shariah side becomes biased and emphasizes more in terms of style or fashion only as part of the lifestyle.

Initially, the use of headscarves among Indonesian teenagers was limited only to female students in Islamic boarding schools. Now, Muslim clothing has become popular with the public in opposition to modernity. This is as stated by Surya (2004: 7) which states that politically headscarves for Islamic women function as opposed to western modernity, namely between religious and secular, public and private spaces, and of course the West and Islam. The veil shows women's commitment to the Islamic way of life and at the same time is a rejection of existing traditions. This shows that the veil can no longer be associated with traditionalism, but rather is a sign of the significance of modernity.

The development of the trend of the use of headscarves as clothing popular among teenagers is strongly influenced by several factors. Apart from the influence of outside culture, mass media also influences the spread of cultural trends popular in the country. The speed of information flow with a wide reach and relatively fast becomes the advantage of mass media in constructing and distributing people's perceptions of popular culture, especially among teenagers. Moreover, the tendency of adolescents who are still in the developmental phase is looking for a selfidentity that is seen according to their wishes. This makes the external culture easy to attract even imitated by teenagers.

At present, the use of headscarves carried out by public figures such as celebrities, state officials, and certain figures increasingly enrich the hijab trend as a popular Muslim dress. The mass media (especially electronic media such as television) constructs people's perceptions of headscarves through certain messages that are packaged into a program. Be it music programs, reality shows, or even soap operas. Public Figure, especially celebrities, is a propaganda tool in campaigning for the hijab dress trend. But sometimes, the use of headscarves as Muslim clothing 
emphasizes the trend side more than the shariah's side. In this position, ordinary people only see the hijab as a dress style that is used not because of recommendations from religious teachings but only as a trend that is often used by public figures or because of the demands of work alone.

Hijabs are packaged in a variety of ways, from the simple to the glamorous, from cheap to expensive, from the ordinary to the ones that are full of accessories. Hijab is easily found anywhere, in traditional markets up to modern markets, in factory outlets, boutiques, or in other modern shopping centers. Headscarves which initially have high sacrality values have now turned into commodity trades that have large economic prospects. Hijab as a religious message that originally had a high sacred sacredness must be willing to be conveyed through a format of mass culture that only relied on extravaganza (pleasure), spontaneity (temporary), latah, less intact, and only relied on commercial desire. Problems in religious discourse will be present when something great is mixed with negative values.

Mass media (such as television) want to produce meaning as a reality provided. A second reality that presents and influences the lives of real readers (audiences). In Fiske's (1994) view all the realities or events that matter (media), have become 'media events'. Where in this 'media event', humans live in the image, even between the image and order of experience there is no difference anymore. Television doctors, television lawyers, television detectives, television economists, television scholars, are considered more real by audiences (Ibrahim, 2007: viii).

Hijab fashion as an influence from popular culture is transmitted through the mass media in various ways. Electronic mass media such as television, for example, transmits the hijab fashion style through music programs, reality shows, films, and soap operas. Movies or soap operas as part of mass communication media are often used as a means to describe the reality of life projected onto a screen. The process of transforming real 
portraits of existing social reality becomes a study material in bringing forth further discourses on human life. In a fundamental view, film or soap operas are said to be a portrait of audio-visual life. The film is a reflection of social reality that is displayed on a screen (Sobur, 2006: 127).

Women who wear headscarves are also found in schools, from staff/employees, teachers to students. Formal education institutions that require citizens to wear headscarves are institutions that are based on Islam, such as madrasa or Islamic private schools, in public schools we can also see that many of their students wear headscarves when they are not wearing headscarves. For example, headscarves are only used when attending certain events or job demands. We find this in many layers of society as a product of globalization such as, which is widely seen on television, entertainment workers often not only wear headscarves because of religious events or in playing certain characters in a film. This indirectly affects anyone who sees it, there is a possibility that the trend "sometimes" imitated by the wider community when unconsciously watching television shows or watching a film (soap opera), Brenner (1998) gives an understanding of symbols that are Indonesian Muslimah identification symbols as part of Islamic countries in the world.

One of the teen soap operas that presents the hijab trend is 'Aisyah Putri'. This soap opera airs every day at 18.00 WIB on RCTI's private TV station. This soap opera was adapted from the "Aisyah Putri" novel by Asma Nadia. Directed by Gita Asmara and Amin Ishak, screenwriter Yanti Puspitasari and produced by Leo Sutanto. This soap opera by Sinemart presents the reality of veiled teenagers who are enough to attract attention. This soap opera tells the colorful life of high school teenagers about the struggle to wear a headscarf during the flow of modernity that cannot be dammed.

The phenomenon of "sometimes" headscarves among adolescents is a study that is quite interesting to study. Besides, the appearance of the 
'Aisyah Putri' soap opera is very relevant to the development of the trend of the use of headscarves among teenagers. Researchers were interested in exploring the correlation of the emergence of religious soap opera 'Aisyah Putri' towards the perception of wearing headscarves among teenagers.

That way, this study aims to analyze how the process of sensation, perception, and confirmation of the trend of wearing headscarves among teenagers. As well as how the effects of exposure to mass media messages in the Aisyah Putri soap opera show for Al-Biruni Bandung High School students are mainly related to cognitive, affective and conative aspects.

\section{Research Question}

From the above background, the focus of the problem finds out the impact on the soap opera Aisyah Putri that aired by RCTI's private television station?

\section{Research Methodology}

The research method used is a qualitative approach by relying on George Gebner's cultivation theory regarding the effects of television media exposure. Stating that the effect of exposure to the media is ideological planting and full of any interests. Cultivation analysis focuses on the contribution of television in giving an audience a picture of reality. Television is the central system of storytelling. Through drama, advertisements, television soap operas carry messages from the media to their homes. In this theory, Gebner discovered a phenomenon he called mainstreaming. The concept of mainstreaming means to go with the flow, meaning that those who watch television with high frequencies will be more trusting than those who rarely. Those who often witness violence on television will be more confident that violence often occurs or is greater in real life than those who are rare. That way, through this concept Gebner, stated that the frequency in watching television will also influence the 
effects of exposure to media received (Dominick, 1998: 519).

At least there are three aspects of media exposure, namely: 1). Cognitive aspects, relating to the symptoms of the mind in the form of knowledge, beliefs, and expectations of objects or groups of objects. 2). Affective aspects, related to feelings in the form of attitudes, motives, perceptions such as antipasti, sympathy, disappointment, happiness, sadness, etc. that are addressed to certain objects. 3). Conative aspects, related to the tendency or partiality of an object, for example, approaching or away from.

Besides, data collection is done through interview techniques, where Albiruni High School students are selected who know the soap opera and its relation to the perception of veiling. Of the 50 Albiruni High School students, there were 30 women and 20 men. So, the research sample amounted to 24 female students consisting of 8 class X students, 8 XI class students and 8 XII class students.

\section{Islamic Religious Soap Opera and Veiled Perceptions}

Simply put, soap operas are an extension of Electronic Cinema. Soap opera is known as the soap opera in English, and the telenovela in Spanish. The soap opera is a play that contains the daily life of the community, packaged through a storyline that is colored by certain conflicts. Soap operas are made to portray or convey certain messages. Soap operas become familiar because the stories that are displayed are very light, contain certain moral messages and are used as certain tools related to portraits of people's lives.

Soap operas as part of mass communication media are often used as a means to describe the reality of life projected onto a screen. The process of transforming real portraits of existing social reality becomes a study material in bringing forth further discourses on human life. 
A film or soap opera is a reflection of the social life of the people displayed on a screen. Films record social portraits that occur in society. Therefore, films or soap operas are often considered as a reflection of social reality (Sobur, 2006: 127). That way, the connection with film as a communication medium signifies that the film is used as a means of conveying messages by the communicator (the filmmaker) to the communicant (audience) through dramatic images that tend to assume the social reality recorded in the community of the creator.

Graeme Turner (Sobur, 2006: 127) rejects the perspective which says that film is only projecting social reality into a screen. For him, such a view is a primitive view that film is merely a reflection of social reality which is then transferred to an audio-visual screen without regard to other elements circulating in the community. Furthermore, Turner argues that film is not merely a means of reflection on the portrait of social life, but rather as a means of representing the reality of society. Where, films try to form and bring reality back based on codes, conventions, and ideologies of their culture. In this view, we try to explore not only explicit meanings but also implicit meanings contained in a social picture that is represented through a film.

Based on their social segment, films have a wide range of influencing their audiences. The relationship between film and society is linear, as part of a social portrait of film that has a significant influence in shaping society based on the message conveyed (Sobur, 2004: 127).

Onong Uchjana Effendy (2000) says that films in the form of soap operas have a dualism of functions. Namely, as an entertainment media (entertainment) and media education (education). As an entertainment medium, often films are used as a means to relieve fatigue and fill one's leisure time. Meanwhile, as a media of education, in simple terms, films always uncover the dimensions of morality in human life. Namely describing messages or "ibrah" from every scene and event played. The 
film is a reflection of the stage of human life staged. How social reality takes place in real life is then transformed into a play that is performed by the actors who as a whole from these various scenes are intertwined so strongly and convey the meaning behind the staged event. So, that way, someone will be awakened about the phenomenon that occurs through the images that are depicted.

Besides, in its function as a medium of education, films are often used as a means of propaganda from certain ideologies. Dennis Mcquail said that in the film there are always elements of ideology and propaganda veiled and expressed in many of the film's phenomenon. Film as an educational medium always displays important messages that influence good or bad for the public (the audience of the film).

The connection with da'wah, often films or soap operas are used as media in preaching. Asep Saeful Muhtadi (2000) (in Nursaparina, 2008: 10) reveals that the liaison between film and da'wah is the same spirit, namely the spirit of conveying moral values and ethical life (Amar Ma'ruf Nahi Munkar). So that the realization of goodness (al-khoir) and guidance (al-huda) in human life to realize a better quality of life.

Da'wah film is a film loaded with Islamic teachings (da'wah messages) which are packaged through a storyline and displayed as attractive as possible through dynamic, auditive and visual moving images. The connection of films about their impact on society shows how a film can influence and shape society in such a way based on the content of the messages contained in it.

As for the soap opera, Ruslani (2005: 3) based on the source of the story, soap operas can be divided into two types, namely: first, soap operas that come from a true story. Namely, soap operas whose stories or ideas are taken from true stories about people, history, events or events, and others. Second, religious soap operas, namely soap operas which are sourced from Islamic teachings that are visualized in the form of images, 
audio, and stories. The idea of the story is taken from classical Islamic sources, both the Qur'an and Hadith.

Thus, Islamic religious soap operas are Islamic religious stories that contain moral messages originating from the Qur'an/al-Hadith or both are poured in the form of soap operas where some of the stories are true stories and some are is a fictional event which is mixed into a story that needs to be learned.

Hijab can be interpreted as a part of Muslim clothing for women in the form of a head covering to cover hair, ears to chest except for the face. Hijab according to Rufaidah (2005: 10-11), explains that the wide veil in the Qur'an is called Khimar or khumur. While the headscarf means collecting or carrying. Besides, headscarves according to some experts in the book Nina Sutrisna (1993: 53-55) are interpreted as follows: (a). according to Lous Ma'luf Yusui, interpreting the headscarf with spacious and spacious clothes or fabrics. (b). Imam Al-Fayumi was an Arabic dictionary compiler oriented to the Islamic problem which interpreted the headscarf as clothing that was looser than a veil, but not like a scarf. (c). Understanding headscarves in general, hijab is a fabric that is not glazed, not thin and has a matching color and is not striking worn on the head by making it cover hair, forehead, and neck. So that it does not reveal part of the hair and does not attract attention from the eyes that look at it.

From the various meanings of hijab, it can be concluded that the hijab does not always have the same meaning for everyone, but basically, the hijab is a mandatory dress for Muslimah because he should cover the aurat in the head to the chest. In this case, the use means veil used to cover the genitals, the time of use is mostly defined by the wearer.

Humans have a desire to relate to factors outside of individual or external factors. This related process is obtained when humans interact. And that interaction depends heavily on the sensory abstraction that perceives external factors in itself. This process is called sensation. 
Furthermore, the sensations carried out by humans towards the outside world will be followed by a process of perception. In simple terms, perception refers to the experience of objects, events, and relationships that are obtained through the process of interpreting or interpreting a message. Perception is an effort to give meaning to sensory senses (Rachmat, 2005: $55)$.

The sensation is an important part of perception. In practice, the process of interpreting meaning involves not only sensation but also attention, interpretation, expectation, motivation, and memory. Thus, perception is the process of interpreting stimuli, experiences, and objects differently.

Some general characteristics of perception include: (a) stimuli received in harmony with sensory modalities; (b) perception has dimensions of space; (c) perception have a time dimension; (d) interlocking structures and contexts; and (e) perception always has meaning and meaning.

Perception is quite important in the context of building similarities in meaning. The Stimulus-Response theory in communication studies states that perception is the whole process that produces responses after stimuli are applied to humans. in this case, perception as a psychological activity has a subprocess, namely recognition, reasoning, and feeling (Sobur, 2003: 446).

In simple terms, the perception process involves three main components, namely first, selection, filtering (filtering) processes from the outside. Second, the interpretation of the process of organizing information. The third selection and interpretation are manifested in the form of behavior or behavior as a reaction.

According to Hurlock (1993: 206-207) adolescence is divided into two parts. The first beginning of adolescence is that it lasts approximately from the age of 13 to 16 years or 17 years. Second, the end of adolescence that starts from the age of 17 years to 18 years, namely the age of legal 
maturity. Behavior is an individual response in the form of both body and speech attitudes. Behavior can be divided into two types: first, closed/ covert behavior includes cognition (stimulation and interpretation), emotions (effects, feelings, and moods), conative (thinking and decision making), and sensing (stimulation to the central nervous system). Second, open behavior includes conscious behavior, reflector behavior (first reflex movement/unconsciousness) and unwanted behavior (not realized).

Thus, soap operas as one of the various films portray the social life of the people who describe and record various social phenomena. Islamic soap opera as a propaganda media has a significant role in conveying religious messages both messages relating to aqeedah, morals, and muamalah. Islamic soap operas can be said to be a medium of propaganda that displays the values of the Islamic law that can be captured by every audience. In the context of mass media, the message (message) displayed on a television screen has a wide range of reach. Portrait of reflection in a film or soap opera has the potential to instill perceptions, sensations, and effects of certain actions.

Based on the results of the interview, the effect of the Aisyah Putri soap opera in the use of headscarves in Al-Biruni High School Bandung referred to the views of Jalaluddin Rakhmat can be seen in the following table:

Table 1. Effects of Aisyah Putri soap opera in the Motivation of Using Hijab at Al-Biruni High School, Bandung

\begin{tabular}{ccl}
\hline No & $\begin{array}{c}\text { Impression } \\
\text { Effect }\end{array}$ & \multicolumn{1}{c}{ Respondents } \\
\hline 1 & Sense & $\begin{array}{l}\text { 24 Respondents stated that they were motivated to use } \\
\text { headscarves, one of which was caused by watching the } \\
\end{array}$ \\
& $\begin{array}{l}\text { Aisyah Putri soap opera. In the process of sensation, the } \\
\text { display on the television screen influences the audience/ } \\
\text { audience motivation. }\end{array}$
\end{tabular}




\begin{tabular}{|c|c|c|}
\hline No & $\begin{array}{c}\text { Impression } \\
\text { Effect }\end{array}$ & Respondents \\
\hline 2 & Perception & $\begin{array}{l}\text { From the Cognitive side, } 14 \text { respondents received the } \\
\text { headscarf concept which was displayed in the Aisyah Putri } \\
\text { soap opera. } 10 \text { respondents considered that there were } \\
\text { aspects that were less aligned between the perception of } \\
\text { headscarves in Aisyah Putri films and what was suggested } \\
\text { in Islam. From the affective side, } 24 \text { respondents expressed } \\
\text { enthusiasm and looked positively with the emergence of } \\
\text { this soap opera. }\end{array}$ \\
\hline 3 & $\begin{array}{l}\text { Confirmation } \\
\text { (Memory and } \\
\text { Thinking) }\end{array}$ & $\begin{array}{l}10 \text { respondents confirmed that one of the motives for } \\
\text { considering the wearing of a headscarf was due to } \\
\text { watching the Aisyah Putri soap opera. } 4 \text { people said } \\
\text { they rejected the hijab concept in the soap opera. And } \\
10 \text { respondents stated that they considered various hijab } \\
\text { concepts that were displayed on the television screen } \\
\text { through the Aisyah Putri soap opera. }\end{array}$ \\
\hline
\end{tabular}

Source: author's observation in 2018

Table 1 above shows that most of the informants stated that there was a large influence on the use of headscarves after watching the soap opera. This is mainly related to the perception of headscarves as fashion that requires a fashionable nature (according to the growing trend) and syarí aspects (sacred values in Islamic teachings). The informant stated that social portraits related to the hijab trend in the soap opera had a significant influence on the use of headscarves in their daily lives. One of them relates to the motivation of informants to use the hijab caused by the shows they witnessed on television screens.

The sensation process is related to the planting of the film of Aisyah Putri which affects the use of headscarves among Al-Biruni High School students in Bandung through sensory abstraction processes based on portraits or shows witnessed. This is also related to the portrait of veiling among teenagers reflected through the media of images and audio in the Aisyah Putri soap opera. The perception process is related to the level of conceptual and affective understanding that affects the mentality 
of Al-Biruni High School students in interpreting the hijab and the use of headscarves. Whereas the confirmation process relates to the level of acceptance obtained through the recording process in memory of the perception of the veil that forms the thinking construction of Al-Biruni Bandung High School students about veiling so that it is in the form of action (confirmation), whether receiving or receiving.

\section{Effects of Media Exposure on Veiled Perceptions Among Adolescents}

The scope of the study of media effects, scholars have discovered three psychological effects carried out by the exposure of the mass media. One of the capabilities of mass media as part of the community is the ability to construct an event based on interests, and certain objectives. Even the mass media can shape social reality as a screen display. Mass media has a significant influence on audience life (Bryan \& Thompson, 2002: 177). These impacts are 1). Cognitive aspects, relating to the symptoms of the mind in the form of knowledge, beliefs, and expectations of objects or objects. 2). Affective aspects, related to feelings in the form of attitudes, motives, perceptions such as antipasti, sympathy, disappointment, happiness, sadness, etc. that are addressed to certain objects. 3). Conative aspects, related to the tendency or partiality of an object, for example, approaching or away from.

Research on the effects of mass media (especially television) has developed over time. So much research has been done, this shows how important mass media is in human life. The mass media either intentional or not has influenced and changed the way of thinking of humans. this was confirmed by Marshal McLuhan, that mass media, including television, has become the dominant force in human life (Dara Hasparmudila, 2009: 2).

The cultivation hypothesis was deliberately developed to explain the influence of television on society. This hypothesis was first introduced by George Gebner and colleagues from the University of Pennsylvania from the United States around the 1960s. 
Cultivation analysis focuses on the contribution of television in giving an audience a picture of reality. Television is the central system of storytelling. Through drama, advertisements, television soap operas carry messages from the media to their homes. In this theory, Gebner discovered a phenomenon he called mainstreaming. The concept of mainstreaming means going with the flow, meaning that those who watch television with a high frequency will be more confident than those who rarely. Those who often witness violence on television will be more confident that violence often occurs or is greater in real life than those who are rare. That way, through this concept Gebner, stated that the frequency in watching television will also influence the effects of exposure to media received (Dominick, 1998: 519).

Another phenomenon that Gebner found was what he called resonance. That is a situation where the response experience or audience is following what is described by the television, thus increasing the effect of cultivation. If television shows are following the viewer's personal experience, then the power of the planting of the ideology will be stronger. Gebner states that television has formed values and attitudes that exist in a culture of society.

Gebner holds that television is a symbolic environment that offers reality through certain symbols. In this position, television has dominated the community environment. When the television is telling about a story, the thing that is more emphasized is how to convey the message system in the same way and repeatedly. Television makes and reflects opinions, images and beliefs that are influenced by their institutional needs (Dara Hasparmudila, 2009: 5-6).

Cultivation analysis begins with message system analysis to identify permanent, continuous, and overarching patterns of television content. The light viewer, medium viewer, and heavy viewer classification are measured by the number of times the respondents watch television on 
average every day. What is important is that there are different levels of watching, not the accurate amount of watching.

Observable evidence of cultivation is relatively simple because even a light viewer can watch television several hours a day and live in the same general culture as a heavy viewer. Therefore, the discovery of consistently different patterns is small but pervasive between light viewers and heavy viewers is very possible (Bryant, J \& D Zillmann: 2002). Small but pervasive shifts in a cultivation perspective can change cultural conditions and reverse the balance of political and social decision making.

From the research conducted, the effect of exposure to Aisyah Putri's religious soap operas on the perception of veiling among teenagers is as follows:

Table.2 Effects of the exposure of Aisyah Putri's Religion TV on the Perception of Youth Veiling at Al-Biruni High School in Bandung

\begin{tabular}{|c|c|c|c|c|c|c|}
\hline \multirow{2}{*}{ No } & \multirow{2}{*}{ Name } & \multirow{2}{*}{ Grade } & \multirow{2}{*}{$\begin{array}{l}\text { Understanding of } \\
\text { Film }\end{array}$} & \multicolumn{3}{|c|}{ Impression Effect } \\
\hline & & & & Cognitive & Affective & Conative \\
\hline 1 & Acih & $\mathrm{X}$ & $\begin{array}{l}\text { Like movies but } \\
\text { rarely watch }\end{array}$ & $\begin{array}{l}\text { Some } \\
\text { understanding of } \\
\text { headscarves was } \\
\text { obtained from the } \\
\text { film but not too } \\
\text { detailed }\end{array}$ & $\begin{array}{l}\text { Sympathy and } \\
\text { Enthusiasm }\end{array}$ & Reflective \\
\hline 2 & $\begin{array}{l}\text { Nurul } \\
\text { Hopipah }\end{array}$ & $\mathrm{X}$ & $\begin{array}{l}\text { Love movies and } \\
\text { watch often }\end{array}$ & $\begin{array}{l}\text { Understand about } \\
\text { some moral values } \\
\text { in veiling }\end{array}$ & $\begin{array}{l}\text { Sympathy and } \\
\text { Enthusiasm }\end{array}$ & $\begin{array}{l}\text { Open Minded } \\
\text { and Reflective }\end{array}$ \\
\hline 3 & $\begin{array}{l}\text { La Beta } \\
\text { Asyahla }\end{array}$ & $\mathrm{X}$ & $\begin{array}{l}\text { Love movies and } \\
\text { watch often }\end{array}$ & $\begin{array}{l}\text { Understand about } \\
\text { some moral values } \\
\text { in veiling }\end{array}$ & $\begin{array}{l}\text { Sympathy and } \\
\text { Enthusiasm }\end{array}$ & Open Minds \\
\hline 4 & Yeti & $\mathrm{X}$ & $\begin{array}{l}\text { Don't like movies } \\
\text { but know it }\end{array}$ & $\begin{array}{l}\text { Some hijab } \\
\text { concepts are not } \\
\text { following the } \\
\text { Shari'a }\end{array}$ & $\begin{array}{l}\text { Antipathy and } \\
\text { Disappointed }\end{array}$ & Closed \\
\hline 5 & Leni & $\mathrm{X}$ & $\begin{array}{l}\text { Like movies but } \\
\text { rarely watch }\end{array}$ & $\begin{array}{l}\text { Understand about } \\
\text { some moral values } \\
\text { in veiling }\end{array}$ & Sympathy & Reflective \\
\hline
\end{tabular}




\begin{tabular}{|c|c|c|c|c|c|c|}
\hline \multirow{2}{*}{ No } & \multirow{2}{*}{ Name } & \multirow{2}{*}{ Grade } & \multirow{2}{*}{$\begin{array}{l}\text { Understanding of } \\
\text { Film }\end{array}$} & \multicolumn{3}{|c|}{ Impression Effect } \\
\hline & & & & Cognitive & Affective & Conative \\
\hline 6 & Ronuroniah & $\mathrm{XI}$ & $\begin{array}{l}\text { Love movies and } \\
\text { watch often }\end{array}$ & $\begin{array}{l}\text { Understand about } \\
\text { some moral values } \\
\text { in veiling }\end{array}$ & Enthusiasm & Open Minded \\
\hline 7 & Hanifah & $\mathrm{XI}$ & $\begin{array}{l}\text { Love movies and } \\
\text { watch often }\end{array}$ & $\begin{array}{l}\text { Understand about } \\
\text { some moral values } \\
\text { in veiling }\end{array}$ & $\begin{array}{l}\text { Sympathy and } \\
\text { Enthusiasm }\end{array}$ & Open Minded \\
\hline 8 & Winda & $\mathrm{XI}$ & $\begin{array}{l}\text { Don't like movies } \\
\text { but know it }\end{array}$ & $\begin{array}{l}\text { Some hijab } \\
\text { concepts are not } \\
\text { following the } \\
\text { Shari'a }\end{array}$ & Sympathy & Reflective \\
\hline 9 & Nurhasanah & $\mathrm{XI}$ & $\begin{array}{l}\text { Don't like movies } \\
\text { but know it }\end{array}$ & $\begin{array}{l}\text { Some hijab } \\
\text { concepts are not } \\
\text { following the } \\
\text { Shari'a }\end{array}$ & Antipathy & Closed \\
\hline 10 & $\begin{array}{l}\text { Khansa } \\
\text { Irawan }\end{array}$ & $\mathrm{XI}$ & $\begin{array}{l}\text { Like movies but } \\
\text { rarely watch }\end{array}$ & $\begin{array}{l}\text { Understand about } \\
\text { some moral values } \\
\text { in veiling }\end{array}$ & Sympathy & Reflective \\
\hline 11 & $\begin{array}{l}\text { Siti } \\
\text { Marpuah }\end{array}$ & XII & $\begin{array}{l}\text { Love movies and } \\
\text { watch often }\end{array}$ & $\begin{array}{l}\text { Understand about } \\
\text { some moral values } \\
\text { in veiling }\end{array}$ & Enthusiasm & Open-Minded \\
\hline 12 & $\begin{array}{l}\text { Salma } \\
\text { Khoirunnisa }\end{array}$ & XII & $\begin{array}{l}\text { Love movies and } \\
\text { watch often }\end{array}$ & $\begin{array}{l}\text { Understand about } \\
\text { some moral values } \\
\text { in veiling }\end{array}$ & $\begin{array}{l}\text { Sympathy and } \\
\text { Enthusiasm }\end{array}$ & Open-Minded \\
\hline 13 & $\begin{array}{l}\text { Nadila } \\
\text { Asfarini }\end{array}$ & XII & $\begin{array}{l}\text { Love movies and } \\
\text { watch often }\end{array}$ & $\begin{array}{l}\text { Understand about } \\
\text { some moral values } \\
\text { in veiling }\end{array}$ & Enthusiasm & Open-Minded \\
\hline 14 & Siti Lilis & XII & $\begin{array}{l}\text { Don't like movies } \\
\text { but know it }\end{array}$ & $\begin{array}{l}\text { Some hijab } \\
\text { concepts are not } \\
\text { following the } \\
\text { Shari'a }\end{array}$ & Sympathy & Reflective \\
\hline 15 & $\begin{array}{l}\text { Dede } \\
\text { Nurhayati }\end{array}$ & XII & $\begin{array}{l}\text { Like movies but } \\
\text { rarely watch }\end{array}$ & $\begin{array}{l}\text { Understand about } \\
\text { some moral values } \\
\text { in veiling }\end{array}$ & Enthusiasm & Open-Minded \\
\hline 16 & Safira & $\mathrm{X}$ & Don't like movies & $\begin{array}{l}\text { Do not understand } \\
\text { the moral value of } \\
\text { the headscarf }\end{array}$ & Antipathy & Closed \\
\hline 17 & Alivia & $\mathrm{X}$ & $\begin{array}{l}\text { Like movies but } \\
\text { rarely watch }\end{array}$ & $\begin{array}{l}\text { Some hijab } \\
\text { concepts are not } \\
\text { following the } \\
\text { Shari'a }\end{array}$ & Sympathy & Reflective \\
\hline 18 & $\begin{array}{l}\text { Devi } \\
\text { Fitriani }\end{array}$ & $\mathrm{X}$ & $\begin{array}{l}\text { Love movies and } \\
\text { watch often }\end{array}$ & $\begin{array}{l}\text { Some hijab } \\
\text { concepts are not } \\
\text { following the } \\
\text { Shari'a }\end{array}$ & Enthusiasm & Open-Minded \\
\hline
\end{tabular}


INJECT (Interdisciplinary Journal of Communication), Vol.4, No.2, Des. 2019: p. 153-174

\begin{tabular}{|c|c|c|c|c|c|c|}
\hline \multirow{2}{*}{ No } & \multirow{2}{*}{ Name } & \multirow{2}{*}{ Grade } & \multirow{2}{*}{$\begin{array}{l}\text { Understanding of } \\
\text { Film }\end{array}$} & \multicolumn{3}{|c|}{ Impression Effect } \\
\hline & & & & Cognitive & Affective & Conative \\
\hline 19 & $\begin{array}{l}\text { Melati } \\
\text { Sukma }\end{array}$ & XI & $\begin{array}{l}\text { Like movies but } \\
\text { rarely watch }\end{array}$ & $\begin{array}{l}\text { Understand about } \\
\text { some moral values } \\
\text { in veiling }\end{array}$ & Sympathy & Reflective \\
\hline 20 & $\begin{array}{l}\text { Safira } \\
\text { Nurjanah }\end{array}$ & XI & $\begin{array}{l}\text { Like movies but } \\
\text { rarely watch }\end{array}$ & $\begin{array}{l}\text { Understand about } \\
\text { some moral values } \\
\text { in veiling }\end{array}$ & Enthusiasm & Open-Minded \\
\hline 21 & $\begin{array}{l}\text { Fatimah } \\
\text { Nur Azmi }\end{array}$ & XI & $\begin{array}{l}\text { Love movies and } \\
\text { watch often }\end{array}$ & $\begin{array}{l}\text { Understand about } \\
\text { some moral values } \\
\text { in veiling }\end{array}$ & Enthusiasm & Reflective \\
\hline 22 & $\begin{array}{l}\text { Diva } \\
\text { Rahmah }\end{array}$ & XII & $\begin{array}{l}\text { Love movies and } \\
\text { watch often }\end{array}$ & $\begin{array}{l}\text { Some hijab } \\
\text { concepts are not } \\
\text { following the } \\
\text { Shari'a }\end{array}$ & Sympathy & Open-Minded \\
\hline 23 & $\begin{array}{l}\text { Siti } \\
\text { Maesaroh }\end{array}$ & XII & $\begin{array}{l}\text { Love movies and } \\
\text { watch often }\end{array}$ & $\begin{array}{l}\text { Some hijab } \\
\text { concepts are not } \\
\text { following the } \\
\text { Shari'a }\end{array}$ & Sympathy & Reflective \\
\hline 24 & Ariska Putri & XII & Don't like movies & $\begin{array}{l}\text { Understand about } \\
\text { some moral values } \\
\text { in veiling }\end{array}$ & Antipathy & Closed \\
\hline
\end{tabular}

(Source: Author Observation 2018)

Based on the table. 2, it was found that: First, from the cognitive aspect, 14 respondents claimed to understand the headscarf concept displayed in the soap opera, 9 respondents viewed that there were several hijab concepts that were not in line with what Islam was saying and 1 person did not understand the connection of soap operas with urgency regarding headscarves.

Second, from the affective aspect, 5 respondents felt sympathy and enthusiasm with the presence of the soap opera, 8 respondents sympathized with the presence of the soap opera, 7 respondents enthusiastically watched the soap opera, 3 antipathy people with the soap opera, 1 person felt antipathy and disappointed with soap opera that is.

Third, from the conative aspect, 10 respondents were open with a moral message in the soap opera and received, 4 respondents were closed and refused the veil concept in the soap opera, 9 respondents took 
a reflective stance did not reject and consider, 1 respondent was open and reflexive with what is shown in the soap opera.

\section{Conclusion}

$\mathrm{Hijab}$ is a mandatory dress for Muslim women who are guided by the teachings of Islam. The headscarf serves to cover women's genitals so that they are maintained and respected. The process of perception of veiling teenagers on Aisyah Putri film shows the stages of sensation, perception, and confirmation (memory and thinking). These three things are related to the process of planting the mind, mentality and behavior in looking at, understanding, accepting and ultimately influencing the motive for the use of headscarves for teenagers.

In the context of perception, teenagers' perceptions of headscarves are much affected by various aspects that come from outside. Whether lifestyle, music or even film. One of the soap operas/films that take the theme of headscarves is the "Aisyah Putri" soap opera that airs on RCTI's private TV station. Hijab perceptions among adolescents can be measured from three aspects, namely cognitive aspects related to knowledge and understanding, affective aspects related to emotional elements and feelings whether sympathy, empathy, antipasti or even enthusiasm and conative aspects related to behavior, namely the tendency to accept or reject, open or closed. The mass media as one of the means of da'wah provides a powerful enough effect for the audience. One of the effects of exposure can instill ideology and interests in the cognitive, affective and conative domains. The headscarf perception among adolescents, especially for students at Albiruni Cerdas Mulia Bandung High School has a strong influence from the effects of exposure to "Aisyah Putri" religious soap operas in terms of cognitive, affective and conative. 


\section{Bibliography}

Burton, Graeme. 2011. Talking Television: An Introduction to The Study of Television (terj : Laily Rahmawati). Yogyakarta: Jalasutra.

Bryan, Jennings, \& Thompson, Susan. 2002. Fundamentals of Media Effects, LEA Publisher, New Jersey.

Bryant, Jennings, dan Dolf Zilmann. 2002. Media Effect, LEA Publisher, New Jersey.

Dara, Hasparmudila. 2009. Efek terpaan media (skripsi). Jakarta: Universitas Indonesia.

Dominick R., Joseph. 1998. The Dynamics of Mass Communication, Sixth Edition, McGraw-Hill College.

Effendy, Onong Uchjana. 2005. Pengantar Ilmu Komunikasi. Bandung : PT Remaja Rosdakarya.

Fitriansyah, Fifit. 2018."Efek Komunikasi Massa Pada Khalayak (Studi

Deskriptif Pengguna Media Sosial dalam Membentuk Perilaku Remaja. Cakrawala". Jurnal Humaniora Bina Sarana Informatika Vol 18, No 2 September 2018.

Fiske, John. 2007. Cultural and Communication Studies cetakan ke 4 (terj : Idy Subandi Ibrahim). Yogyakarta : Jalasutra.

Hurlock, Elizabeth, B. 2006. Psikologi Perkembangan. Jakarta : Erlangga. 1993. Perkembangan Anak. Jakarta : Erlangga.

Imran, Hasyim Ali. 2012. "Media Massa, Khalayak Media, The Audience Theory, Efek Isi Media dan Fenomena Diskursif". Jurnal Studi Komunikasi dan Media Vol 16, No 1 Tahun 2012.

M.A. Moleong. J,L. 2007. Metode Penelitian Kualitatif. Bandung. PT Remaja Rosdakarya.

McQuail, Dennis. 2000. Mass Communication Theory, An Introduction, Fourth Edition, Sage Publication. London- Thousand Oak-New Delhi.

Nina, S. 2002. Anggunnya Berjilbab. Bandung: Balai pustaka. 
Raden Aditya Novianto, et al. "Pengaruh Terpaan Media Terhadap Perubahan Sikap Dari Tayangan Sinetron '7 Manusia Harimau' di Kalangan Remaja Sma Kota Bandung. e-Proceeding of Management", Vol 3, No.1 April 2016.

Rakhmat, Jalaludin. 2005. Psikologi Komunikasi. Bandung: Rosdakarya. 2002. Metode Penelitian Komunikasi. Bandung: Rosdakarya.

Rufaidah, A. 2005. Anggun Berkerudung di Segala kesempatan. Jakarta: PT Gramedia Pustaka Utama.

Sambas, Syukriadi dkk. 2009. Dimensi Ilmu Tabligh. Bandung: WIdya Padjadjaran.

Sobur, Alex. 2004. Analisis Teks Media. Bandung: PT Remaja Rosdakarya. Suharsimi, Arikunto. 1998. Prosedur Penelitian Suatu Pendekatan Praktek. Jakarta: Rineka Cipta.

Surya,Y,W.I. 2004. "Citra Perempuan Islam Kontemporer: Representasi Perempuan Islam dalam Sinetron Ramadhan. Surabaya". Journal Unairre. Dalam Masyarakat, kebudayaan dan politik. Vol 17. No 4. Widowati, Dewi. 2012. "Efek Media Massa Terhadap Khalayak". Jurnal Adzikra, Vol. 03, No.1, (Januari-Juni) 2012.

\section{Internet}

Amalia, Rizqi. 2015. Efek Tayangan On The Spot terhadap Pesan Media Massa Bagi Mahasiswa Ilmu Komunikasi Universitas Mulawarman. E-JournalIlmu Komunikasi,3, (2)2015:30-42, ejournal.ilkom.fisipunmul.org.

Moqsit Ghazali, Abdul. Sinetron Religius,http://id.wikipedia.org/w/ index.php. diakses pada 18 desember 2018.

Novriantoni. 2005. Kasus Jilbab Padang dan Fasisme Kaum Moralis. http:// www.digdaya.com/kasus-jilbab-padang-dan-fasisme-kaummoralis.html (27 FEB 2013) 
INJECT (Interdisciplinary Journal of Communication), Vol.4, No.2, Des. 2019: p. 153-174

this page intentionally left blank 